\title{
THE DEER OF EPPING FOREST
}

\section{By Anthony Buxton}

My home was on the edge of Epping Forest and my father, the late Edward North Buxton, was a very active verderer of that forest for practically the whole of his life. He was moreover in the forefront of the fight to save the forest as an open space for the public. From very early days I was constantly in the forest and at once began to take an interest in its deer.

In Saxon times and for centuries later a large proportion of Essex was covered by woods, heather and grassy commons. Even at the end of the sixteenth century Camden wrote " Near the Sey (sea) spreads out a chase of vast extent, full of game, the largest and fattest deer in the Kingdom ". In the reign of King John the grievances of the forest laws became so intolerable that he was compelled to limit the royal forest to what was known as the Forest of Waltham, stretching from the River Lea on the west to the Romford sound on the east, and these boundaries were confirmed by Edward I. King Charles I attempted to enlarge these boundaries but the sturdy people of Essex rebelled and held a "conventicle in the very brake where the King's stag should have been lodged for his hunting the next morning ". As a result the Long Parliament passed an Act fixing the forest boundaries to comprise 60,000 acres. Up to the time of Henry VIII nearly the whole of the ownership of the forest soil was vested in the religious bodies of the day, subject to the sporting rights of the Crown. At the Reformation rights which had been held by the monasteries reverted to the Crown. Queen Elizabeth I constantly hunted in Epping Forest. From at least pre-Norman times until the end of the seventeenth century every other interest was subordinate to the maintenance of the sporting rights of the Crown. Then when this function of the forest lapsed by disuse, it was considered a public duty to bring waste land into cultivation. Still later came the idea that the vast population of London and other cities needed open spaces for fresh air and recreation, and also the idea, which has been well adhered to in Epping Forest, that those open spaces ought to harbour the wild animals and the wild vegetation that did exist and ought to exist in a wild forest.

In 1859 Epping Forest, owing to numerous enclosures, had dwindled to 6,000 acres and during the next twenty years half this area was fenced in and partly built upon. Despite protests from the newly-formed "Commons Preservation Society" further enclosures continued, but public opinion was hardening 
and at last came a definite open act of resistance. A labourer called Willingale persisted in asserting his ancient right of "lopping" trees on Loughton Manor in Epping Forest. The case was brought before the local justices and treated by them as a theft: Willingale was sent to prison. However, the Commons Preservation Society took up the case and supported the "lopping right". The Lords of the Manor succeeded in persuading the Government to bring forward a bill which would have reduced the forest open to the public to 600 acres, with leave to purchase another 400 acres, the whole of the remaining 5,000 acres to be made over to the Lords of the Manor. The Commons Preservation Society took a strong line : the bill was vigorously opposed and dropped. Subsequently, despite the Government's opposition, an address to the Crown was passed calling upon it to preserve those parts of the forest which had not been enclosed by legal authority. Then the Corporation of the City of London stepped in and in 1871 a suit was started against the Lords of the Manor, which lasted more than three years, cost both sides $£ 30,000$, and only ended in 1874 in a final hearing, which lasted 17 days, before the Master of the Rolls, Sir George Jessel. His judgment, which overthrew all the enclosures, was never questioned. The forest of roughly 6,000 acres was saved for the public and so were its deer.

All our three native deer - red deer, fallow, and roe-have inhabited Epping Forest, but now only the fallow remain. Until the early part of the nineteenth century red deer had free range of the forest and heads of red stags killed in the forest, in the possession of the Lord of the Manor of Loughton, showed that these deer compared more than favourably with Scottish red deer. A very old inhabitant stated in $\mathbf{1 8 7 1}$ that he remembered quite a number of red deer roaming in the forest when he was young. "There was a kennel," he said, " at Loughton Bridge kept by a man named Dean and the hounds and horses of the hunt were kept there. A paddock was enclosed with high palings and in this enclosure the deer, caught wild from the forest, were kept and hunted as required, but not killed. The black deer (fallow) were hunted two or three times a week, killed, and used as required also. The method of taking the red deer was by fixing a net (kept at Loughton Bridge for the purpose and about a mile long) from the milestone in the forest down to Monk Wood. The deer were driven up from Monk Wood into it. Two or three were selected and the rest, with the young ones, set at liberty. A cart for the purpose was in readiness and the deer caught were placed in it and taken to Loughton 
Bridge where they were kept in the paddock till wanted." A Mr. Lory Pole Wellesley, who lived at Wanstead House, kept a pack of stag hounds in a style of princely magnificence, the hunt servants dressed in Lincoln green. He apparently only hunted the red deer, but the pace was too hot to last and his establishment was broken up in 1797. A London publicanTommy Rounding-bought a few of the hounds, which he kept at Woodford Wells. Rounding continued to hunt the red deer of the forest until, about twenty years later, a royal order was issued that the red deer were to be caught up and taken to Windsor Park. The few red deer that escaped the nets fell victims to poachers, until only one old stag remained. This stag was hunted by Tommy Rounding and after a great run was killed at West Ham. Except for a few brought back from Windsor later in the century, which must soon have strayed, there have never been any red deer in Epping Forest since.

Fallow deer are generally stated to be non-indigenous and are supposed to have been introduced by the Romans; but I have recently seen the horn of a fallow buck, found in this country, dating from the time when it was a promontory and not an island. This horn, in my opinion, completely knocks out the Roman origin theory. It is a magnificent horn, but it differs no more from the horn of a modern fallow buck than does a red stag's horn from Scotland differ from a red stag's horn from the Caucasus or Asia Minor. Fallow, always the most numerous deer in the forest, vary greatly in colour from a quite pale coat covered with spots to practically black. The Epping Forest deer are far the blackest fallow that I have ever seen-much darker than those of the New Forest. They have no white under their tails and the spots typical of fallow can only be seen at very close range and in bright sun. The horns of an Epping Forest buck are far less palmated than those of normal park fallow. Unfortunately, in quite recent years, this special breed of black Epping Forest fallow has been contaminated by other fallow that roam about Essex and have no doubt escaped from parks. I saw last year for the first time in the forest a fallow with white under its tail and a distinctly lighter coat than that of a true Epping Forest deer. The fallow stray from the forest into some of the neighbouring woods and it is difficult therefore to make an accurate count of their numbers. The latest counts in the forest are :-1950, 146 fallow; 1951, 173; 1952, 104. They suffer in the present day from the motor traffic through the forest, particularly on the London-Epping road; accidents are frequent and may be fatal, not only to the deer. Many fallow 
fawns are bound to be caught by dogs when they are too young to escape. It is not difficult, at any rate for anyone with some idea of woodland stalking, to see the fallow in Epping Forest. They are of course used to constantly seeing people walking about and are not very wild, but they are good "slinkers" and know how to conceal themselves. Moreover the stem of a pollard hornbeam makes very good camouflage for a dark fallow. The grazing in the forest is naturally far from good, but during hard weather the fallow make full use of the abundant growth of holly and I have often seen them standing on their hind legs to browse on the most tender foliage. When I was a small boy I used to go out in search of deer with a Norwegian elk hound, which is trained to wind deer direct and to pull its human master, to which it is attached by a cord, straight towards the deer. I was several times pulled clean off my young legs. With such assistance there is little difficulty in finding the deer. My object was to get as near as possible and my only weapon was a walking stick. I learnt a good deal about silent woodland stalking, the way of the wind and the habits of deer.

I have often wondered what, if any, is the purpose of that very large Adam's apple which graces the throat of a fallow buck. The pig-like grunt of a buck in the rutting season in November, never seems quite a large enough sound to account for the size of that Adam's apple. No other deer that I know has such a prominent feature on the throat and yet some of them can make a much more awe-inspiring noise than the grunt of a fallow buck. I have not the same affection for fallow that I have for red deer and roe, but they make me laugh, particularly when they move off with that ridiculous stilted gait, as though they expected every moment to step on a hot brick.

The roe were always my favourites in Epping Forest and alas they are there no more. In 1883, when I was two years old, my father introduced (or rather re-introduced) roe deer to Epping Forest. With the help of Mr. Maxwell Pleydell and Mr. C. Hambro, two Dorsetshire proprietors in whose woods roe were common, and under the superintendence of Mr. J. E. Harting, a keen naturalist, six roe-two bucks and four does-were caught in nets in Dorsetshire and safely released in Epping Forest. These deer thrived but were always extremely conservative in their tastes, confining themselves strictly to certain very limited areas of the forest and to certain woods just outside it at Copped Hall, near Epping. In the forest itself the two Monk Woods and the valley dividing them formed by the brook which issues from Wake Valley pond, a quite small area by Loughton Camp and another small area in Chingford Thicks 
were the only portions of the forest in which $I$ ever saw a roe. In fact they preferred the Copped Hall woods and there they were not popular. Gradually roe diminished in the forest and I believe that the last survivor was seen by my father in 1923 . It is a very sad loss. I have of recent years tried to probe the secret of this most fascinating, and mysterious animal and have what seems to me strong evidence that there is a certain thing which roe simply must have. I think that their strict geographical distribution in Epping Forest and its surroundings depended probably upon that something.

I have a vivid recollection of a roe incident just behind the Roebuck inn on the London-Epping road. I was a boy of 10 or 12, entirely alone in the forest, when in a little open space with very sparse covert I saw a roe doe. She spotted me and instantly squashed down on to the ground with her chin a newly-born fawn. I went straight to the spot and searched and searched, while the doe circled round me not thirty yards off making perpetually a most distressful call. I never found that fawn and finally came away feeling rather guilty and very foolish.

The impertinent face of a roe with the eyes rather close together and that cheeky black and white snub nose has always made me feel that a roe must laugh. Now at last I know that they do, and audibly. I was standing within a few feet of a tame roe doe in a garden wherein it was at liberty. The roe missed nothing - a wood-pigeon flying over the garden, the banging of a door, the barking of a dog, the passing of a car! All were noticed with interest and apparently with amusement. Presently a calf in a neighbouring meadow danced across the grass. I not only saw that roe laugh, I heard it-a little miniature whinny, very infectious. A roe cannot only laugh, it can swear and that at nine months old. This doe objected to being collared by its mistress and shoved into its kennel to prevent its eating the roses while we had lunch. There was a terrible struggle and in the middle of it I heard a loud and angry grunt. My hostess disclaimed any responsibility ; it was the roe who had sworn.

It is a pleasant thought that despite all the changes that have occurred recently in this country, we still have within from 11 to 16 miles of the Bank of England wild deer, wild badgers and wild foxes, and that anybody who knows how to set about it can see them there. Much the easiest to see are of course the deer, but I once watched for over an hour on a June evening, while seated in the crown of a pollard hornbeam, just above the main badger earth in the forest, one vixen, ten fox cubs, and seven badgers - and that within 14 miles of the Bank of England. 